\title{
Penerapan Problem Based Learning Berbantuan LKS untuk Meningkatkan Self-Efficacy dan Hasil Belajar Matematika
}

\section{Ketut Bawa*}

SMA Negeri 1 Singaraja

\author{
A R T I C L E I N F O \\ Article history: \\ Received 19 February 2019 \\ Received in revised form \\ 30 March 2019 \\ Accepted 10April 2019 \\ Available online 20 May \\ 2019
}

Kata Kunci:

Problem Based Learning

LKS, Self Efficacy, Hasil

Belajar.

Keywords:

Problem Based Learning, Students' Worksheet, SelfEfficacy,
Students'Achievement

\begin{abstract}
A B S T R A K
Penelitian ini adalah penelitian tindakan kelas yang bertujuan untuk meningkatkan self efficacy dan hasil belajar matematika siswa kelas XI Bahasa SMA Negeri 1 Singaraja pada semester genap tahun pelajaran 2018/2019, melalui penerapan model problem based learning berbantuan LKS. Penelitian ini melibatkan 22 orang siswa kelas XI Bahasa SMA Negeri 1 Singaraja pada semester genap tahun pelajaran 2018/2019. Penelitian tindakan ini dilaksanakan mengikuti prosedur penelitian tindakan yang dikemukakan oleh Hopkins sebanyak 2 siklus, Setiap akhir siklus dikumpulkan data hasil belajar siswa dengan tes hasil belajar dengan tujuan untuk melihat perkembangan hasil belajar matematika siswa. Di samping itu sebelum dan sesudah tindakan, dikumpulkan data self-eficacy siswa melalui kuisioner self efficacy. Setelah semua data terkumpul dan dianalisis secara deskriptif, penelitian ini menyimpulkan bahwa model problem based learning berbantuan LKS dapat meningkatkan self efficacy dan hasil belajar matematika siswa kelas XI Bahasa SMA Negeri 1 Singaraja pada semester genap tahun pelajaran 2018/2019. Hal ini dibuktikan dari adanya peningkatan skor rata-rata self efficacy siswa sebesar $39,68 \%$ dari rata-rata skor 92,65 (kategori cukup) sebelum tindakan menjadi 129,41 pada akhir siklus II (kategori tinggi). Demikian juga hasil belajar
\end{abstract} matematika siswa meningkat sebesar $7,73 \%$ yakni dari rata-rata nilai 64,00 pada siklus I, menjadi 68,95 pada siklus II. Dilihat dari ketuntasan belajar siswa secara klasikal juga mengalami peningkatan sebesar $59,96 \%$ yakni dari $22,73 \%$ pada siklus I menjadi $36,36 \%$ pada siklus II.

A B S T R A C T

This action research aims at increasing self-efficacy and achievements on mathematics of students XI Bahasa of SMA Negeri 1 Singaraja on second semester acedemic year 2018/2019 through the implementation of problem based learning assisted by students' worksheets. This research involved 22 students of XI Bahasa SMA Negeri 1 Singaraja on second semester academic year 2018/2019. This research was conducted in two cycles which followed a research procedure by Hopkins in each cycle which consisted of planning, acting, observing-evaluating, and reflecting. At the end of each cycle the data about students' achievements were collected by using mathematical achievement test in order to know the increasing the students' achievements. Besides that, before and after treatments conducted it was collected data about students'self-efficacy by using questionnaire. Data collected were analyzed descriptively, the research concluded that problem based learning assisted by students'worksheets could increase self efficacy and mathematical achievements of students XI Bahasa SMA Negeri 1 Singaraja on second semester academic year 2018/2019. It could be seen from the increasing of students'self-efficacy $39.68 \%$ from average score of self-efficacy 92.65 (sufficient category) before treatment became 129.41 at the end of cycle II (high category). And also the achievements on mathematics of students XI Bahasa SMA Negeri 1 Singaraja increased from $7.73 \%$ from average score 64.00 in cycle I became 68.95 in cycle II. From the classical average score on mathematics also increased $59.96 \%$ from $22.73 \%$ in cycle I became $36.36 \%$ in cycle II.

Copyright (C) Universitas Pendidikan Ganesha. All rights reserved. 


\section{Pendahuluan}

Proses perkembangan pemikiran dan peradaban umat manusia sangat ditentukan oleh perkembangan pendidikan pada zamannya. Dengan kata lain pendidikan merupakan kebutuhan dasar manusia sepanjang hayat. Menurut UU RI No. 20/2003 tentang Sistem Pendidikan Nasional, pendidikan berfungsi untuk mengembangkan kemampuan dan membentuk watak serta peradaban bangsa yang bermartabat dalam rangka mencerdaskan kehidupan bangsa, bertujuan untuk berkembangnya potensi peserta didik agar menjadi manusia yang beriman dan bertaqwa kepada Tuhan Yang Maha Esa, berakhlak mulia, sehat, berilmu, cakap, kreatif, mandiri, dan menjadi warga Negara yang demokratis serta bertanggung jawab (UU Sisdiknas No. 20/2003). Ini berarti bahwa pendidikan dilaksanakan dalam rangka membentuk watak manusia Indonesia, dan meningkatkan kualitas sumber daya manusia. Lebih jauh dijelaskan bahwa pendidikan diharapkan mampu menghasilkan sumber daya manusia yang profesional, dan memberi respon terhadap perubahan yang terjadi dalam masyarakat.

Dalam kurikulum 2013 pendidikan dikembangkan berbasis pada nilai-nilai luhur, nilai akademik, kebutuhan peserta didik dan masyarakat, bertujuan untuk membangun sumber daya manusia Indonesia yang beriman, berkemanusiaan, berpengetahuan, dan keterampilan. Khusus untuk pembelajaran matematika, penerapannya diarahkan agar peserta didik mampu berpikir rasional dan kreatif, mampu berkomunikasi dan bekerjasama, jujur, konsisten, dan tangguh menghadapi masalah serta mampu mengubah masalah menjadi peluang. Untuk itu pembelajaran matematika harus mampu menjembatai pencapaian tujuan tersebut melalui proses pembelajaran yang relevan dan kontekstual.

Proses pembelajaran yang relevan dan kontektual adalah proses pembelajaran yang mampu menjawab masalah kekinian dan tantangan masa depan. Saat ini, sekalipun teknologi telah berkembang sangat pesat, namun pembelajaran matematika masih cenderung konvensional, yakni siswa meniru apa yang dijelaskan dan ditunjukkan guru di depan kelas. Pembelajaran matematika masih berorientasi pada pencapaian hasil akhir dan sering mengabaikan proses. Hal ini berdampak pada belum baiknya hasil belajar matematika siswa.

Selain model pembelajaran, keberhasilan siswa dalam belajar banyak ditentukan oleh faktor psikologis, satu diantaranya adalah faktor keyakinan diri (efikasi diri) siswa dalam belajar (Bandura, 1997). Efikasi diri adalah suatu keyakinan individu bahwa dirinya mampu mengelola dan memutuskan tindakan yang diperlukan untuk melaksanakan tugas dengan baik. Siswa yang memiliki efikasi diri tinggi memiliki harapan yang kuat untuk sukses, gigih saat menghadapi rintangan, dan cenderung menentukan tujuan yang menantang (Gredler, 2011). Sedangkan, siswa yang memiliki efikasi diri rendah pada umumnya dihinggapi perasaan gagal, yang akhirnya menuju kepada hasil yang kurang memuaskan dan menjadikan kepercayaan dirinya rendah. Hal ini berarti bahwa efikasi diri memiliki peranan yang penting di dalam hasil belajar siswa.

Berdasarkan uraian di atas peneliti merasa tertantang untuk melakukan perubahan paradigma dalam pembelajaran matematika, dari pembelajaran konvensional ke pembelajaran kooperatif. Pembelajaran kooperatif dipilih karena pembelajaran kooperatif merupakan pembelajaran fundamental dalam menghadapi kehidupan. Ashley Montagu (Lickona, 2013) menyatakan bahwa kerjasama (bukannya konflik), telah terbukti merupakan bentuk perilaku yang paling bermanfaat bagi manusia pada setiap tingkatan sejarah evolusi mereka. Joel Thornley (Lickona, 2013) juga menyatakan membuat murid-murid duduk tenang di mejanya masing-masing, dan bukannya membiarkan mereka bekerjasama adalah suatu pertaruhan dimana kita kalah sepanjang tahunnya. Artinya pembelajaran kooperatif adalah pembelajaran mengenai dasar-dasar kehidupan.

Salah satu model pembelajaran kooperatif yang berlandaskan filosofi konstruktivisme adalah pembelajaran Problem-Based Learning. Model pembelajaran ini diyakini peneliti akan berdampak pada efikasi diri siswa dan hasil belajar matematika siswaj0-9.

\section{Metode}

Penelitian ini merupakan penelitian tindakan kelas (PTK) yang dilaksanakan di SMA Negeri 1 Singaraja, untuk semua siswa kelas XI Bahasa pada semester genap tahun pelajaran 2018/2019, yang berjumlah 22 orang. Objek utama yang diteliti dalam penelitian ini adalah capaian kompetensi pada kompetensi dasar barisan dan deret, dan kompetensi dasar limit, serta keyakinan diri siswa dalam menyelesaikan permasalahan. Pelaksanaan tindakan,merupakan pelaksanakan tindakan dalam kelas sesuai dengan Rancangan Pelaksanaan Pembelajaran yang telah disusun. Adapun pelaksanaan pembelajaran dengan menerapkan model pembelajaran Inkuiri berbantuan media konkret. (a) Kegiatan Pendahuluan: Guru melakukan apersepsi, guru memberikan motivasi kepada siswa, guru menyampaikan tujuan dan rencana kegiatan penbelajaran. (b) Kegiatan Inti: siswa mendengarkan penjelasan dari guru, 
guru menerapkan model pembelajaran Inkuiri berbantuan media konkret, siswa berdiskusi dalam kelompok dengan bimbingan guru. (c) Kegiatan Penutup: siswa bersama guru membuat kesimpulan dari kegiatan pembelajaran, guru melakukan refleksi penutup kegiatan pembelajaran, siswa mengerjakan tes yang diberikan guru.

Penelitian ini dilaksanakan dalam dua siklus, di mana masing-masing siklus terdiri dari empat tahapan, yakni: 1) perencanaan, 2) pelaksanaan, 3) observasi-evaluasi, dan 4) refleksi. Rancangan penelitian digambarkan pada Gambar 1.

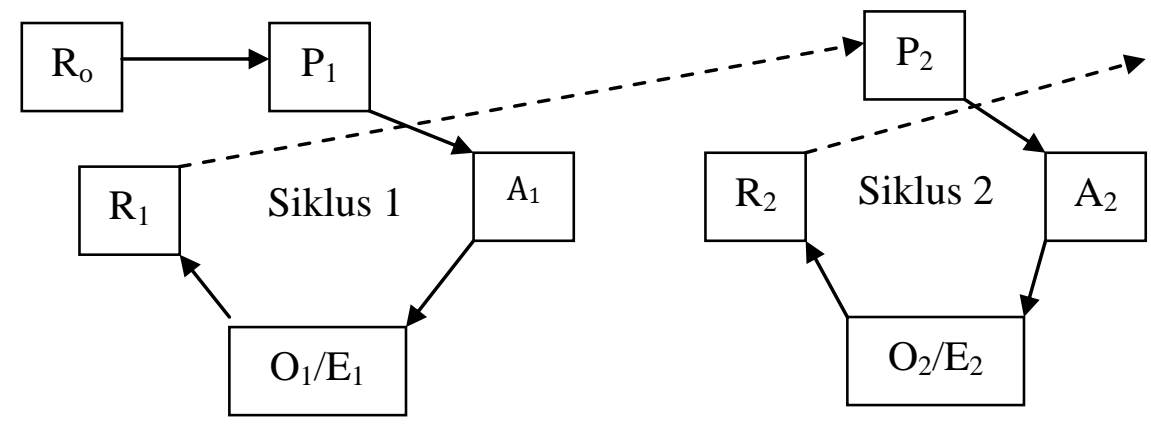

Gambar 1. Rancangan Penelitian Tindakan Kelas

Diadopsi dari Hopkins dalam Arikunto (2006)

Keterangan:

Ro

$\mathrm{Ri}$

$\mathrm{Pi}$

: Perencanaan tindakan pada siklus ke-i

$\mathrm{Ai} \quad$ : Pelaksanaan tindakan pada siklus ke-i

Oi/Ei : Observasi dan evaluasi pada siklus ke-i

i

$: 1,2,3, \ldots$

Penelitian ini menggunakan dua instrumen untuk mengumpulkan data, yaitu instumen berupa tes hasil belajar dan kuisioner self efficacy. Tes pencapaian kompetensi matematika disusun dalam bentuk tes uraian. Sedangkan kuisioner self efficacy menggunakan instrumen yang sudah ada, yakni instrument yang disusun peneliti pada saat menyelesaikan studi S3.

Data hasil belajar dikumpulkan pada setiap akhir siklus dan kuisioner sefl efficacy diberikan pada awal dan akhir penelitian/tindakan. Data yang telah terkumpul dianalisis secara deskriptif untuk memperoleh gambaran mengenai tingkat keberhasilan penerapan model Probem-Based Learning berbantuan LKS. Formula yang digunakan untuk mencari rata-rata skor adalah, dengan adalah rata-rata skor, adalah jumlah skor, dan $\mathrm{N}$ adalah banyaknya siswa.

Penerapan model pembelajaran dengan model Problem-Based Learning berbantuan LKS dalam pembelajaran matematika untuk kelas XI Bahasa SMA Negeri 1 Singaraja pada semester genap tahun pelajaran 2018/2019, dianggap berhasil, apabila memenuhi indikator keberhasilan : 1) Skor rata-rata capaian hasil belajar matematika minimal 75,00 atau dalam klasifikasi baik, 2) Ketuntasan belajar secara klasikal minimal 80\%, dan 3) Keyakinan diri siswa (self-efficacy) meningkat di akhir siklus dari awal siklus.

\section{Hasil dan Pembahasan}

a. Deskripsi Awal Pembelajaran

Penelitian tindakan kelas ini dilaksanakan pada siswa kelas XI Bahasa SMA Negeri 1 Singaraja pada semester genap tahun pelajaran 2018/2019. Sebagai gambaran umum, berikut profil siswa di kelas XI Bahasa SMA Negeri 1 Singaraja pada semester ganjil tahun pelajaran 2018/20189.

Tabel 1. Profil siswa Kelas XI Bahasa SMA Negeri 1 Singaraja pada semester ganjil tahun pelajaran 2018/2019.

\begin{tabular}{|c|c|c|}
\hline No & Data & Keterangan \\
\hline 1 & Jumlah siswa & 18 Orang \\
\hline 2 & Jumlah siswa laki & 4 Orang \\
\hline
\end{tabular}




\begin{tabular}{lll}
\hline 3 & Jumlah siswa perempuan & 22 Orang \\
4 & Rata-rata nilai matematika pra-tindakan & 58,82 (Klasifikasi Cukup) \\
5 & Ketuntasan belajar secara klasikal & $4,55 \%$ \\
\hline
\end{tabular}

b. Hasil Penelitian Siklus I

Pembelajaran dalam siklus I melibatkan materi Barisan dan Deret, disajikan dalam 8 kali pertemuan.

1) Perencanaan Siklus I

Kegiatan dalam perencanaan siklus I diantaranya: a) menyiapkan rencana pelaksanaan pembelajaran (RPP) untuk materi Barisan dan Deret, b) menyiapkan lembar kerja siswa (LKS) yang memuat pokok-pokok permasalahan yang akan menjadi pemicu untuk memulai satu pembelajaran, c) menyiapkan bahan untuk evaluasi hasil belajar.

2) Pelaksanaan Siklus I

Sesuai dengan rencana yang telah disusun, dan berdasarkan situasi yang dihadapi, pelaksanaan atau pemberian tindakan pada siklus I dilaksanakan selama $8 \times$ pertemuan, masing-masing $2 \times 45$ menit.

3) Observasi-Evaluasi Siklus I

Kegiatan observasi pada siklus I dilakukan sepanjang proses pembelajaran sikus I berlangsung. Halhal pokok yang menjadi perhatian peneliti dalam mengobservasi proses pembelajaran adalah: a) kegiatan siswa dalam diskusi kelompoknya, b) perhatian siswa pada saat presentasi hasil diskusi kelompok, c) aktivitas siswa selama diskusi yang dipimpin oleh guru. Hasil observasi siklus I menunjukkan bahwa siswa belum mampu menggunakan kemampuannya dalam menganalisis masalah kontekstual yang diberikan dalam lembar aktivitas siswa. Selanjutnya untuk melihat efektivitas atau taraf keberhasilan tindakan dalam siklus I dilakukan tes evaluasi belajar. Hasil evaluasi siklus I menunjukkan bahwa rata-rata capaian kompetensi siswa kelas XI Bahasa untuk kompetensi dasar barisan dan deret sebesar 64,00 (klasifikasi cukup). Ketuntasan klasikal yang mampu dicapai untuk siklus I sebesar 22,73\%.

4) Refleksi Siklus I

Refleksi dilakukan dengan tujuan untuk melihat kelemahan dan kelebihan selama proses pembelajaran dan hasil yang dicapai dalam siklus I. Berdasarkan hasil refleksi akhir siklus I, diperoleh bahwa indikator keberhasilan penelitian belum terpenuhi, yakni rata-rata hasil belajar minimal 75,00 dan ketuntasan belajar secara klasikal sebesar minimal 80,00\%. Capaian rata-rata hasil belajar baru mencapai 64,00 dengan ketuntasan belajar secara klasikal sebesar 22,73\%. Hal ini berarti rencana tindakan kedua dilanjutkan dengan melakukan perbaikan-perbaikan sesuai hasil refleksi siklus I.

c. Hasil penelitian siklus II

Pembelajaran dalam siklus II melibatkan materi Limit disajikan dalam 6 kali pertemuan.

1) Perencanaan Siklus II

Kegiatan dalam perencanaan siklus II diantaranya: a) menyiapkan rencana pelaksanaan pembelajaran (RPP) untuk materi Limit, b) menyiapkan lembar aktivitas siswa (LKS) yang memuat pokok-pokok permasalahan yang akan menjadi pemicu untuk memulai satu pembelajaran, c) menyiapkan bahan untuk evaluasi hasil belajar kompetensi dasar limit.

2) Pelaksanaan Siklus II

Sesuai dengan rencana yang telah disusun dan melihat situasi yang dihadapi, pelaksanaan tindakan pada siklus II dilaksanakan selama $6 \times$ pertemuan, masing-masing $2 \times 45$ menit.

3) Observasi-Evaluasi Siklus II

Kegiatan observasi pada siklus II dilakukan sepanjang proses pembelajaran sikus II berlangsung. Halhal pokok yang menjadi perhatian peneliti dalam mengobservasi proses pembelajaran adalah: a) kegiatan siswa dalam diskusi kelompoknya, b) perhatian siswa pada saat presentasi hasil diskusi kelompok, c) aktivitas siswa selama diskusi yang dipimpin oleh guru. Hasil observasi siklus II menunjukkan bahwa sebagian besar siswa telah mampu melakukan diskusi dengan baik dan tidak membatasi diri dalam diskusi dalam kelompoknya saja, namun sudah berkembang melakukan diskusi antar kelompok dan sesekali mengajukan pertanyaan pada guru. Selanjutnya untuk melihat efektivitas atau taraf keberhasilan pemberian tindakan dalam siklus II dilakukan tes evaluasi belajar. Hasil evaluasi siklus II menunjukkan rata-rata nilai hasil belajar siswa pada siklus II untuk materi Limit sebesar 68,95 (klasifikasi Baik), dengan tingkat ketuntasan klasikal sebesar 36,36\%.

4) Refleksi Siklus

Hasil refleksi akhir siklus II, menunjukkan bahwa indikator keberhasilan penelitian masih belum terpenuhi, yakni rata-rata hasil belajar minimal 75,00 dan ketuntasan belajar secara klasikal sebesar 
minimal 80,00\%. Capaian rata-rata hasil belajar baru mencapai 68,95 dengan ketuntasan belajar secara klasikal sebesar $36,36 \%$. Hal ini berarti tindakan berikutnya perlu direncanakan dengan melakukan perbaikan-perbaikan sesuai hasil refleksi siklus II. Namun mengingat sudah ada peningkatan hasil belajar, baik dari segi rata-rata hasil belajar maupun ketuntasan belajar secara klasikal, maka laporan hasil penelitian tindakan kelas sudah dapat dilakukan sesuai realita yang dihadapi.

d. Data Efikasi Diri Siswa

Data self efficacy siswa telah dikumpulkan dengan kuisioner sefl efficacy sebelum tindakan sebesar 92,86 (kategori cukup) dan sesudah tindakan sebesar 129,41 (kategori tinggi). Skor masingmasing individu ditunjukkan dalam Gambar 2 berikut.

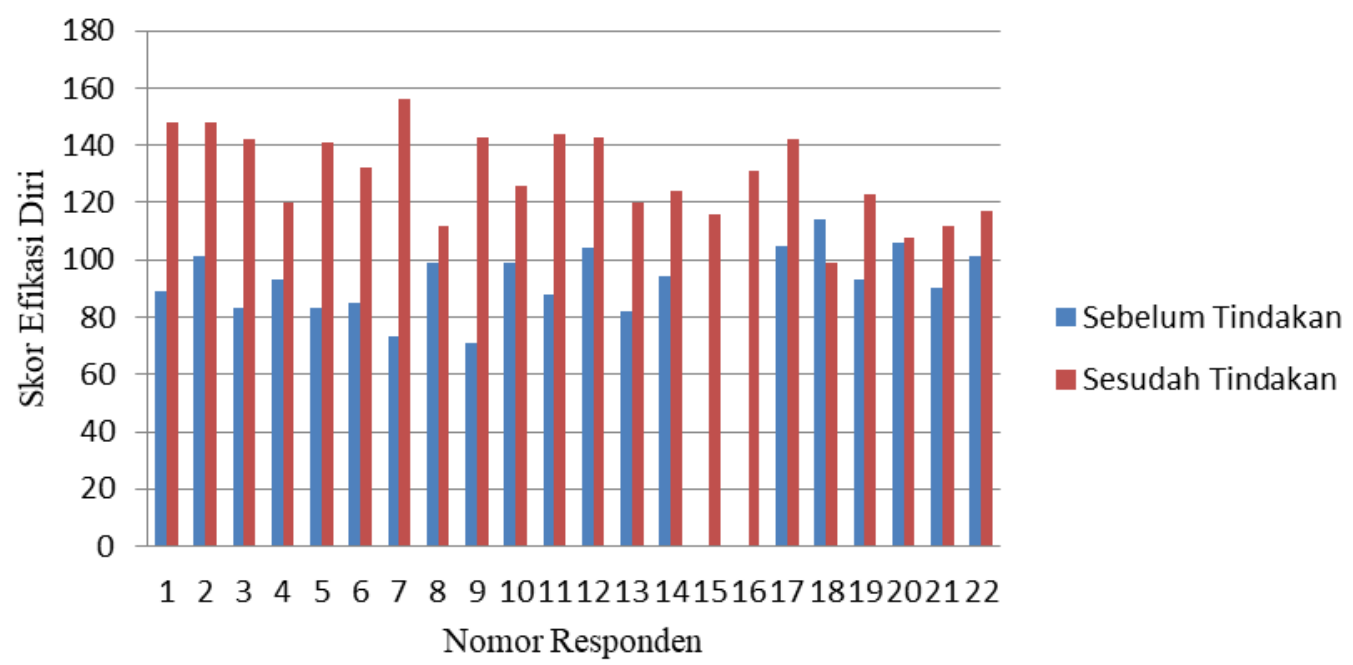

Gambar 2. Grafik Skor Efikasi Diri Siswa

e. Peningkatan Hasil Penelitian

Berdasarkan data hasil belajar siklus I dan siklus II, dapat dilihat bahwa terdapat peningkatan hasil belajar dan ketuntasan belajar matematika siswa. Secara rinci data hasil belajar matematika siswa diuraikan dalam tabel dan grafik berikut.

Tabel 2. Peningkatan Hasil Belajar dan Ketuntasan Belajar Siswa

\begin{tabular}{cccc}
\hline No & Siklus & Rata-Rata Hasil Belajar & Tingkat Ketuntasan \\
\hline 1 & Pra & 58,82 (Cukup) & $4,55 \%$ \\
2 & I & 64,00 (Cukup) & $22,73 \%$ \\
3 & II & 68,95 (Baik) & $36,36 \%$ \\
\hline
\end{tabular}

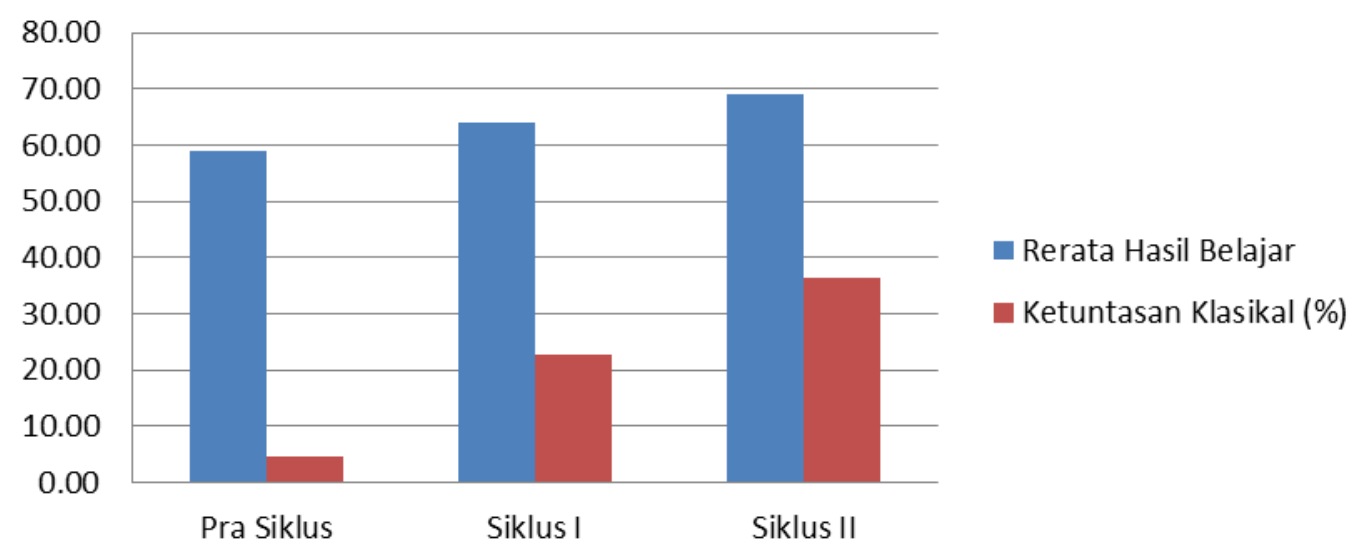

Gambar 3. Grafik Peningkatan Hasil Belajar Siswa 
Sedangkan peningkatan skor efikasi diri siswa, dari sebelum dan setelah tindakan, dapat dilihat pada tabel dan grafik berikut.

Tabel 3. Data Skor Efikasi Diri Siswa

\begin{tabular}{|c|c|c|c|c|c|c|}
\hline \multirow[b]{2}{*}{ Data } & \multirow{2}{*}{$\begin{array}{c}\text { Rata-Rata } \\
\text { Skor }\end{array}$} & \multirow[b]{2}{*}{ Klasifikasi } & \multicolumn{4}{|c|}{ Jumlah Siswa dengan Klasifikasi } \\
\hline & & & Rendah & Cukup & Tinggi & $\begin{array}{l}\text { Sangat } \\
\text { Tinggi }\end{array}$ \\
\hline $\begin{array}{l}\text { Sebelum } \\
\text { Tindakan }\end{array}$ & 92,86 & Cukup & $\begin{array}{c}7 \\
(31,82 \%)\end{array}$ & $\begin{array}{c}15 \\
(68,18 \%)\end{array}$ & $\begin{array}{c}0 \\
(0 \%)\end{array}$ & $\begin{array}{c}0 \\
(0 \%)\end{array}$ \\
\hline $\begin{array}{l}\text { Setelah } \\
\text { Tindakan }\end{array}$ & 129,41 & Tinggi & $\begin{array}{c}0 \\
(0 \%)\end{array}$ & $\begin{array}{c}11 \\
(50,00 \%)\end{array}$ & $\begin{array}{c}11 \\
(50,00 \%)\end{array}$ & $\begin{array}{c}0 \\
(0 \%)\end{array}$ \\
\hline Keterangan & Naik & Naik & Turun & Turun & Naik & Tetap \\
\hline
\end{tabular}

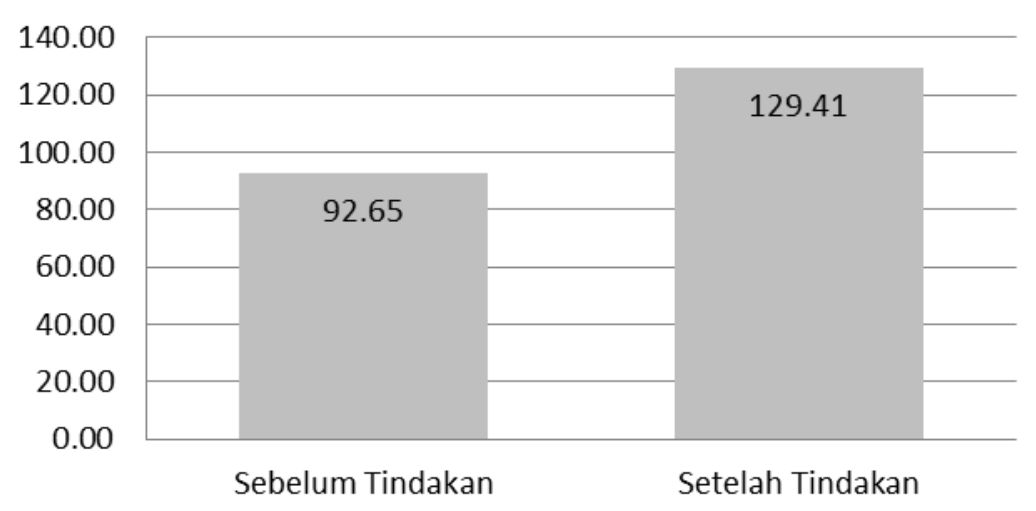

Gambar 4. Grafik Peningkatan Skor Rata-Rata Efikasi Diri Siswa

Berdasarkan data-data hasil penelitian dan catatan hasil-hasil refleksi dalam setiap siklus, dapat dikatakan bahwa pembelajaran matematika dengan model Problem-Based Learning berbantuan LKS dapat meningkatkan self efficacy dan hasil belajar siswa kelas XI Bahasa SMA Negeri 1 Singaraja dalam belajar matematika. Hal ini dapat dilihat dari adanya peningkatan skor rata-rata self efficacy dan hasil belajar siswa dalam matematika.

Dilihat dari rata-rata hasil belajar siswa, terjadi peningkatan sebesar 8,81\% yakni dari nilai ratarata 58,82 (kategori cukup) sebelum diberikan tindakan meningkat menjadi 64,00 (kategori cukup) pada siklus I, dan meningkat kembali sebesar 7,73\% menjadi 68,95 (kategori baik) pada siklus II dari siklus I. Dilihat dari ketuntasan belajar secara klasikal juga mengalami peningkatan sebesar 399,56\% yakni dari ketuntasan belajar sebesar 4,55\% sebelum tindakan diberikan meningkat menjadi 22,73\% pada siklus I, dan meningkat kembali sebesar 59,96\% menjadi 36,36\% pada siklus II dari siklus II.

Jika dibandingkan dengan kriteria keberhasilan penelitian tindakan kelas yang telah ditetapkan dapat dikatakan bahwa capaian nilai rata-rata kelas belum mencapai target 75,00, dan capaian untuk ketuntasan klasikal juga belum mencapai kriteria yang ditetapkan yakni minimal 80,00\%. Namun demikian, data juga menunjukkan terjadi peningkatan hasil belajar secara individu sebesar 63,64\%.

Dilihat dari skor rata-rata self efficacy siswa, terjadi peningkatan sebesar 39,68\% yakni dari nilai rata-rata 92,65 atau dalam klasifikasi cukup pada sebelum diberikan tindakan, menjadi 129,41 atau klasifikasi tinggi pada akhir siklus II. Jika dibandingkan dengan kriteria keberhasilan penelitian tindakan kelas yang ditetapkan dapat dikatakan bahwa capaian skor rata-rata efikasi diri siswa sudah mencapai target yakni adanya peningkatan skor efikasi diri siswa. Data juga menunjukkan adanya peningkatan skor efikasi diri siswa secara individu sebesar 95,00\%.

Hal ini menggambarkan bahwa sekalipun tidak semua indikator keberhasilan penelitian dipenuhi, namun kecenderungan data memberi petunjuk bahwa tindakan yang diberikan mempengaruhi hasil belajar dan efikasi diri siswa dalam belajar matematika. Dapat dikatakan bahwa penerapan model problem based learning berbantuan LKS dalam pembelajaran matematika dapat meningkatkan hasil belajar dan efikasi diri siswa dalam belajar matematika. Adanya peningkatan keyakinan diri siswa dalam belajar ini berimplikasi pada adanya peningkatan hasil belajar siswa. Hal ini beralasan karena di dalam 
proses pembelajaran dengan model problem based learning siswa diberikan kesempatan untuk mencoba menggunakan kemampuannya secara kolaboratif di dalam menyelesaikan permasalahan yang dihadapi secara ilmiah, yang memungkinkan tumbuhnya rasa percaya/yakin pada diri siswa.

Berdasarkan catatan-catatan selama observasi dapat dikemukakan bahwa ada permasalahan mendasar yang harus mendapat perhatian. Permasalahan tersebut adalah kemampuan siswa dalam melakukan analisis masih kurang kurang. Di samping itu kemampuan siswa dalam melakukan manipulasi aljabar masih kurang. Data ini dapat dilihat secara jelas dalam proses penyelesaian masalah yang diberikan guru saat siswa mengerjakan lembar aktivitas siswa. Kecenderungan siswa hanya mampu menyelesaikan permasalahan matematika yang sudah dalam bentuk masalah matematika. Hal ini tentu belum sesuai dengan tuntutan kurikulum di tingkat sekolah menengah yang menuntut level pengetahuan minimal level kemampuan menganalisis.

Adanya peningkatan hasil dalam penelitian ini juga dipengaruhi oleh adanya aktivitas yang kooperatif dari seluruh peserta didik, dan keterlibatan masalah-masalah kontekstual, dan mekanisme kerja menuruti sistem kerja ilmiah. Hal ini beralasan karena penerapan model belajar berbasis masalah (PBL) dalam pendidikan sebaiknya 1) kooperatif, penggunaan kelompok kerja kooperatif membantu perkembangan masyarakat belajar dalam kelas. Penelitian-penelitian menunjukkan bahwa hasil belajar pebelajar meningkat dalam lingkungan belajar kooperatif. Bekerja dalam kelompok juga membantu mengembangkan karakteristik esensial yang dibutuhkan untuk sukses setelah pebelajar tamat, seperti dalam komunikasi secara lisan, berkomunikasi secara tertulis, dan keterampilan membangun tim kerja, 2) kontekstual, pebelajar memperoleh pengetahuan ilmiah dalam konteks dimana pengetahuan itu digunakan. Pebelajar akan mempertahankan pengetahuannya dan menerapkannya dengan tepat bila konsep-konsep yang mereka pelajari berkaitan dengan penerapannya, sehingga pebelajar menyadari makna dari pengetahuan yang mereka pelajari, 3) bekerja ilmiah, menyediakan cara efektif untuk mengubah pembelajaran abstrak ke konkrit dengan memperkenalkan masalah-masalah yang relevan pada awal pembelajaran, pengajar dapat menarik perhatian dan minat pebelajar, serta memberikan kesempatan pada mereka untuk belajar melalui pengalaman. Percakapan dan kolaborasi secara tidak resmi yang dilakukan dalam diskusi dalam proses pemecahan masalah dapat menumbuhkan suasana kolaborasi.

Selain adanya peningkatan hasil belajar, dalam penelitian ini juga terjadi peningkatan efikasi diri siswa. Dengan adanya perbaikan efikasi diri siswa terhadap belajar matematikanya, siswa memiliki usaha sendiri untuk mewujudkan keyakinannya tersebut. Semakin tekun usahanya semakin baik hasilnya. Tampaknya hal inilah yang terjadi di dalam kelas XI Bahasa. Setelah sepanjang proses pembelajaran matematika dilaksanakan dengan berbagai penekanan pada motivasi dan peningkatan keyakinan bahwa "kalian pasti bisa", tampak bahwa siswa-siswa memiliki semangat dalam belajar. Hal ini ditunjukkan dari antusiasme dalam melaksanakan diskusi kelompok dan adanya keberanian siswa untuk bertanya berulang kali.

Semakin baik proses pembelajaran yang dilaksanakan akan meningkatkan peran serta peserta didik. Keterlibatan peserta didik yang optimal menunjukkan ketertarikan mereka dalam mengikuti proses pembelajaran. Jika ketertarikan peserta didik ini terus dapat dipertahankan maka sangat berpotensi di dalam meningkatkan rasa percaya diri siswa dalam belajar matematika, terlebih peserta didik memperoleh hasil belajar yang baik. Dengan kepercayaan diri yang baik, peserta didik akan merasa yakin mampu menyelesaikan masalah-masalah matematika selanjutnya jika terus mengiktui proses pembelajaran matematika yang menyenangkan.

a) Observasi kegiatan guru

Dari data hasil observasi dapat dilihat bahwa skor kegiatan guru pada siklus I pertemuan pertama diperoleh skor sebesar 21 dengan kategori cukup dan mengalami peningkatan pada pertemuan kedua yaitu memperoleh skor 25 dengan kategori baik sehingga jumlah skor dari kedua pertemuan tersebut adalah 46 dan skor rata-rata kegiatan guru yang diperoleh adalah 23. Hal ini berarti aktivitas guru pada siklus I berada pada skor $21 \mathrm{~s} / \mathrm{d}<26$ yang termasuk dalam kategori baik. Hasil ini sudah memenuhi kriteria keberhasilan yang ingin dicapai yakni kegiatan guru minimal tergolong dalam kategori baik. Data rekapitulasi hasil observasi siklus I dapat dilihat pada tabel berikut.

Artinya dengan penerapan model pembelajaran Problem-Based Learning berbantuan LKS akan menumbuhkan self efficacy siswa untuk belajar matematika dengan baik dan hasil belajar matematikapun menjadi lebih baik.

\section{Simpulan Dan Saran}

Sesuai dengan hasil penelitian dan pembahasan yang telah diuraikan, hasil penelitian tindakan kelas dengan tindakan berupa penerapan model Problem-Based Learning berbantuan LKS dalam 
pembelajaran matematika menghasilkan kesimpulan bahwa: 1) Self efficacy siswa kelas XI Bahasa SMA Negeri 1 Singaraja, semester genap tahun pelajaran 2018/2019 dalam belajar matematika dapat ditingkatkan melalui penerapan model Problem-Based Learning berbantuan LKS. 2) Hasil belajar matematika siswa kelas XI Bahasa SMA Negeri 1 Singaraja, semester genap tahun pelajaran 2018/2019 dapat ditingkatkan melalui penerapan model Problem-Based Learning berbantuan LKS.

Sejalan dengan hasil penelitian sebagaimana disimpulkan di atas, saran peneliti antara lain: 1) Model Problem-Based Learning berbantuan LKS agar diterapkan oleh guru matematika khususnya, terutama untuk topik-topik yang memiliki banyak kaitannya dengan dunia nyata siswa, sehingga pembelajaran matematika menjadi semakin bermakna dan menarik bagi siswa untuk lebih menekuninya. 2) Untuk menumbuhkembangkan keyakinan diri siswa, hendaknya para guru terus menumbuhkan semangat belajar dan keyakinan diri siswa dalam belajar, khususnya belajar matematika. 3) Dibutuhkan waktu yang lebih banyak untuk menerapkan model pembelajaran PBL berbantuan LKS, untuk itu agar direncanakan dengan sangat matang sehingga tujuan kurikulum tercapai dan tujuan mulia pembelajaran berbasis masalah juga terjadi. 4) Mengingat sampai laporan ini disusun belum semua indikator keberhasilan penelitian tindakan kelas terpenuhi maka masih dibutuhkan tindakan selanjutnya dengan melakukan berbagai perbaikan sesuai hasil refleksi pada akhir siklus II.

\section{Daftar Rujukan}

Arends, Ricard I. 2008. Learning to Teach, Belajar untuk Mengajar, Edisi Ketujuh, Buku Satu: alih bahasa Helly P S. Yogyakarta: Pustaka Pelajar.

Arikonto, Suharsimi. 2013. Dasar-Dasar Evaluasi Pendidikan, Edisi 2. Jakarta: Bumi Aksara.

Azwar, Saifuddin. 2015. Tes Prestasi, Fungsi dan Pengembangan Pengukuran Prestasi Belajar. Yogyakarta: Pustaka Pelajar.

Bahri, Djamarah Syaiful. 2002. Psikologi Belajar. Jakarta: Rineka Cipta.

Bandura, Abert. 1997. Self-Efficacy in Change Societies. New York: Cambridge University Press.

Bandura, Abert. 1986. Social Foundations of Thought and Action. New Jersey: Prentice-Hall, Inc.

Bloom, S. Benjamin. 1971. Handbook on Formative and Sumative of Student Learning. New York: McGrawHill Book, Co.

Candiasa, I Made. 2010. Statistik Univariat dan Bivariat Disertai Aplikasi SPSS. Singaraja: Unsdiksha Press.

Dantes, N. 2014. Landasan Pendidikan, Tinjauan dari Dimensi Makropedagogis. Singaraja: Program Pascasarjana Universitas Pendidikan Ganesha.

Gagne, Robert M. 1990. Kondisi Belajar dan Teori Pembelajaran, Terjemahan: Munandir, Handy Kartawinata. Jakarta: Depdikbud.

Gie, The Liang. 1999. Filsafat Matematika . Yogyakarta: Pusat Belajar Ilmu.

Gredler, Margaret E. 2011. Learning and Instruction, Teori dan Aplikasi, Edisi Keenam. Jakarta: Kencana.

Ginnis, Paul. 2008. Trik \& Taktik Mengajar, Strategi Meningkatkan Pengajaran di Kelas. Jakarta: Indeks.

Goleman, Daniel. 1998. Working with Emotional Intelegence. London: Bloomsbury Publishing Plc.

Gormally,C., Brickman.2015.Effects of Inquiry Based Learning on Students Science Literacy Skill and Confidence. International Journal for the Scholarship of Teaching and Learning. 3 (2). 31-37. Tersedia pada http://www.doi.org Diakses 8 Desember 2017.

Hanafiah, Nanang dan Suhana, Cucu. 2009. Konsep Strategi Pembelajaran. Bandung: Refika Aditama.

Hamalik, Oemar. 2008. Proses Belajar Mengajar. Jakarta: Bumi Aksara. 
Ibrahim, R.,\& Syaodih, N. 2003. Perencanaan Pengajaran. Jakarta: PT. Rinika Cipta

Jerolimek, John \& Cliford D. Foster. 1976. Teaching and Learning in the Elementary School. New York: Macmillan Publishing Co. Inc.

Jihad, Asep \& Abdul Haris. 2008. Evaluasi pembelajaran. Yogyakarta: Multi Pressindo

Juniati, Ni Wayan dan I Wayan Widiana. (2017). Penerapan Model Pembelajaran Inkuiri Untuk Meningkatkan Hasil Belajar IPA. Jurnal Ilmiah Sekolah Dasar. Vol.1 (1) pp. 20-29.

Jus Pariatna, I Wayan \& Ida Bagus Nyoman Sudria, Ngadiran Karto Wasono. 2015. "Pengembangan Perangkat Pembelajaran Inkuiri Terbimbing pada Topik Laju Reaksi”. Jurnal Wahana Matematika Dan Sains, Volume 9, Nomor 1, April 201538.

Koes-H, Supriyono. 2012. "Pengaruh Strategi Scaffolding-Kooperatif dan Pengetahuan Awal terhadap Prestasi Belajar dan Sikap pada Matakuliah Fisika Dasar". e-Journal Penelitian Jurusan Teknologi Pembelajaran, Program Pascasarjana Universitas Negeri Malang. Tahun 2012.

Kosasih, E. 2014. Strategi Belajar dan Pembelajaran: Implementasi Kurikulum 2013. Bandung: Yrama Widya.

Lickona, Thomas. 2013. Educating for Character, Mendidik untuk Membentuk Karakter, Bagaimana Sekolah dapat Mengajarkan Sikap, Hasrat dan Tanggung Jawab. (Terjemahan : Juma Abdu Wamaungu). Jakarta: Bumi Aksara.

Lukma, Ika. 2014. "Penerapan Model Inkuiri Melalui Pemberian Bantuan (Scaffolding) untuk Meningkatkan Pemahaman Siswa Kelas V SD dalam Mata Pelajaran Fisika". E-Journal Pendidikan Program Studi Pendidikan Dasar-Matematika SD, Program Pascasarjana, Universitas Negeri Malang. 7(2). 27-43. Tersedia pada http://www.unm.ac.id. Diakses pada 6 Mei 2017.

Marfuqotul Hidayah, Sutama. 2015. Penerapan Problem Based Learning untuk Peningkatan Kemampuan Pemecahan Masalah Matematika. FKIP UMS

Marheni, Ni Putu \& I Nyoman Suardana. "Pembelajaran Inkuiri Terbimbing Berbasis Budaya Lokal pada Pembelajaran Sains Kimia SMP”. Jurnal Wahana Matematika dan Sains, Volume 8 Nomor 2, Oktober 2014 (87)

Mariati. Y. 2014. Pengaruh Model Inkuiri Terbimbing Berbasis Lingkungan terhadap Keterampilan Kreatif dan Penguasaan Konsep IPA Kelas V SD e-Journal STKIP NU Indramayu, Jawa Barat 6 (12). 1-5. Tersedia pada http://www.stkippnuiac.id. Diakses pada 23 April 2017

Metaputri, Ni Kadek dan Ni Nym. Garminah. 2016. "Pengaruh Model Pembelajaran Inkuiri Terbimbing dan Minat Belajar terhadap Keterampilan Proses Sains pada Siswa Kelas IV SD”. Jurnal Pendidikan dan Pengajaran, Jilid 49, Nomor 2, Juli 2016, hlm. 89-97

Nurkancana, Wayan \& Sunartana. 1990. Evaluasi Hasil Belajar. Surabaya: Usaha Nasional

Purwanto. 2009. Evaluasi Hasil Belajar. Yogyakarta: Pustaka Pelajar

Purwanto, M. Ngalim. 2000. Psikologi Pendidikan. Bandung: Remaja Rosdakarya.

Runtukahu, Tombokan \& Selpius Kandou. 2014. Pembelajaran Matematika Dasar Bagi Anak Berkesulitan Belajar. Yogyakarta: Ar-Ruzz MediPa.

Sanjaya, Wina. 2006. Strategi Pembelajaran Berorientasi Standar Proses Pendidikan. Jakarta: Kencana

Santyasa, I Wayan. 2012. Pembelajaran Inovatif. Singaraja: Undiksha Press. 
Sharan, Shlomo. 2009. Handbook of Cooperative Learning. Alih bahasa: Sigit Prawoto. Yogyakarta: Imperium.

Santrock, John W. 2008. Psikologi Pendidikan, Alih Bahasa: Tri Wibowo B.S. Jakarta: Kencana Prenada Media Group.

Schunk, D.H. 1995. "Self-Efficacy, Motivation, and Perfomance". Journal of Applied Sport Psychology 7(2), 112-137 (diakses: 22 Desember 2016)

Slavin, R. E. 2015. Cooperative learning: Theory, Research, and Practice. Second edition. Boston: Alyn and Bacon.

Slameto. 2003. Belajar dan Faktor-Faktor yang Mempengaruhinya. Jakarta: Rineka Cipta.

Subarinah, Sri. 2006. Inovasi Pembelajaran Matematika SD. DEPDIKNAS

Sudjana, Nana. 2011. Dasar-Dasar Proses Belajar Mengajar. Bandung: Sinar Baru Algensindo

Sugiyono. 2014. Metode Penelitian Kombinasi (Mixed Methods). Bandung: Alfabeta

Sumarti.S.,Rahayu.S.,Madlazim.2015. "Pembelajaran IPA dengan Inkuiri Terbimbing Menggunakan Hypermedia dan Media Riil Ditinjau gaya Belajar dan Kemampuan Awal". Jurnal Pendidikan \& Pembelajaran. 2 (2). 45-52. Tersedia pada http://www.unes.ac.id_. Diakses 8 April 2017.

Sumiati \& Asra. 2011. Metode Pembelajaran. Bandung: CV Wacana Prima

Suryaningsih, Ni Made Ayu \& I Made Elia Cahaya, Christiani Endah Poerwati. 2016. "Implementasi Pembelajaran Inkuiri Terbimbing Berbasis Permainan dalam Meningkatkan Kreativitas Anak Usia Dini". Jurnal Pendidikan Indonesia Vol. 5, No. 2, Oktober 2016 (212-220).

Susanto, Ahmad. 2013. Teori Belajar Pembelajaran di Sekolah Dasar. Jakarta: Kencana

Suparno, Paul. 1997. Filsafat Konstruktivisme Dalam Pendidikan. Yogyakarta: Kanisius.

Trianto. 2009. Mendesain Model Pembelajaran Inovatif Progresif : Konsep, Landasan, dan Implementasi pada Kurikulum Tingkat Satuan Pendidikan (KTSP). Jakarta: Kencana.

Undang-Undang Republik Indonesia Nomor 20 tahun 2003 tentang Sistem Pendidikan Nasional. Jakarta.

Walle, John A. Van De, Karen S. Karp \& Bay-Williams, Jennifer M. 2013. Elementary and Middle School Mathematics Teaching Developmentally, Eighth Edition. USA: Pearson Education, Inc. 